\title{
Liquidity Risk and Return to Islamic Interbank Money Market Development
}

\author{
Mochamad Malik Akbar Rohandi \\ Faculty of Economics and Business - Management, Universitas Islam Bandung (UNISBA) \\ moch.malik@gmail.com
}

\begin{abstract}
The purpose of this study is to determine the effect of risk management of Islamic banking liquidity, determine the factors that cause the relationship of influence between the management of liquidity risk and IIMM Return, and knowing the prospects of risk management issues of Islamic bank liquidity concern to the development of IIMM. This research use descriptive and ARCH and GARCH Method. The results show the variant of EGARCH $(1,1)$ as the best model with $R^{2} 1.44 \%$. The Factors affect to IIMM are FDR, STM and Return. This research contributes to sharia banking in determining liquidity risk management where sharia IIMM can develop when sharia banking is in a condition of shortage liquidity, volatility sharia IIMM have quite stable condition.
\end{abstract}

Keywords: ARCH and GARCH, IIMM Volume, Liquidity Risk, Return, Risk of STM and FDR

\begin{abstract}
ABSTRAK
Tujuan dari penelitian ini adalah untuk mengetahui pengaruh manajemen risiko likuiditas perbankan syariah, menentukan faktor-faktor yang menyebabkan hubungan pengaruh antara manajemen risiko likuiditas dan IIMM Return, dan mengetahui prospek masalah manajemen risiko dari kekhawatiran likuiditas bank syariah untuk pengembangan IIMM. Penelitian ini menggunakan metode deskriptif dan ARCH dan GARCH. Hasilnya menunjukkan varian EGARCH $(1,1)$ sebagai model terbaik dengan R2 1,44\%. Faktor-faktor yang mempengaruhi IIMM adalah FDR, STM dan Return. Penelitian ini memberikan kontribusi bagi perbankan syariah dalam menentukan manajemen risiko likuiditas di mana IIMM syariah dapat berkembang ketika perbankan syariah berada dalam kondisi kekurangan likuiditas, volatilitas IIMM syariah memiliki kondisi yang cukup stabil

Kata Kunci: ARCH dan GARCH, Volume IIMM, Risiko Likuiditas, Return, Risiko STM dan FDR
\end{abstract}




\section{INTRODUCTION}

\section{Background}

Low interest in Islamic bank in conducting liquidity risk management in the Islamic Interbank Money Market (IIMM) led to sluggish development of IIMM which is still represented by two instruments, first Certificate of Mudharabah Interbank Investment and Certificate of Commodity Trading based on Islamic principles. IIMM can lead to potential liquidity risk because one of the keys that must be done in order to remain liquid banking has access to the money market to obtain any necessary funds (Riyadi, 2006). High proportion of liquidity management of Islamic banking at the central bank instruments led the development of the Islamic financial market became constrained and less than optimal (Alam, 2012).
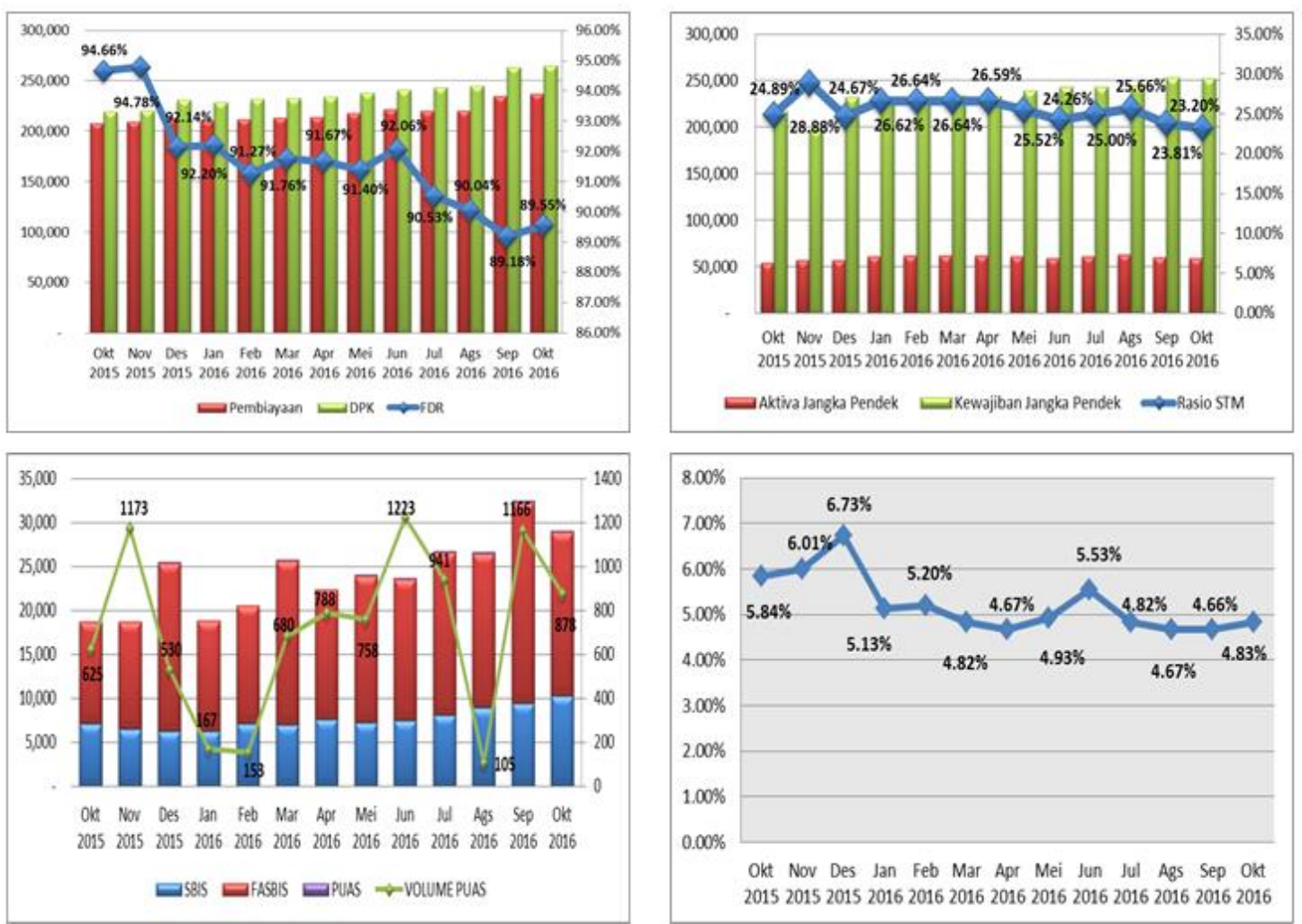

Figure 1. Outstanding FASBIS, SBIS, IIMM and Volume IIMM, Financing, DPK, FDR ratio, STM ratio and Return of IIMM

(Source: Islamic Bank Statistic data and OJK, Data Processing Result) 
It shows Outstanding FASBIS, SBIS, IIMM and Volume IIMM, Financing, Depositor Fund (DPK), Finance to Deposits Ratio (FDR), Short Term Mismatch (STM) ratio and IIMM Return. The volume growth in Islamic interbank money market transactions is not significant when compared with developments placement instrument in central bank liquidity management, it shows low interest in conducting banking transactions on the interbank money market liquidity which may create risk. The picture shows that there is a mismatch in term of assets that have an average of more than two years and liabilities with an average term of less than two years.

\section{Problem Identification}

Research questions for this study: 1 . Why liquidity management in Islamic bank influence the development of IIMM? 2. What factors are affecting the development of IIMM? 3. How does the prospect of liquidity risk management issues to the development of Islamic banking IIMM?

\section{LITERATURE REVIEW}

High of Finance to Deposits Ratio (FDR) describe the high level of liquidity risk faced by Islamic bank industry (Wahyudi, et al., 2013). Liquidity risk occurs when the bank unable to match the timeframe of the asset and its liability (Van Greuning and Iqbal, 2011).

According to Muhammad (2002), the placement of idle funds in Islamic banking on monetary instrument of IIMM is still a subjective decision and based on maximizing profit motive. Widyastuti and Anwar (2009) concluded that the placement of idle funds in Islamic banking should be placed on SWBI instrument due to having a more minimal risk and impact compared with IIMM. Halim Alamsyah as Deputy Governor of Bank Indonesia stated that the high portion in central bank instrument caused the development of Islamic interbank money market became constrained and not optimal (Alamsyah, 2012). 


\section{METHOD}

IIMM has an unstable tendency or volatile and the implication high volatile data is that the variant of the error is not constant or heteroskedasticity (Juanda and Junaidi, 2012). Models that can utilize heteroscedasticity in error appropriately result in more efficient estimators known as (ARCH) and (GARCH) (Nachrowi and Usman, 2006).

This research used descriptive analysis and ARCH and GARCH models analysis. The data used secondary data in the form of monthly time series data obtained from the Indonesian Banking Statistics (IBS) and Islamic Banking Statistics of Bank Indonesia, starting from October 2010 until October 2016.

Data Variable for this research was the Volume of Islamic interbank money market (VIIMM), STM ratio (STM), FDR ratio (FDR), Level of Return IIMM transaction (Return).

Regression models ARCH and GARCH equation in this study is

VIIMMt Stmt $=\beta 0+\beta 1+\beta 2+\beta 3$ FDRt Return + et
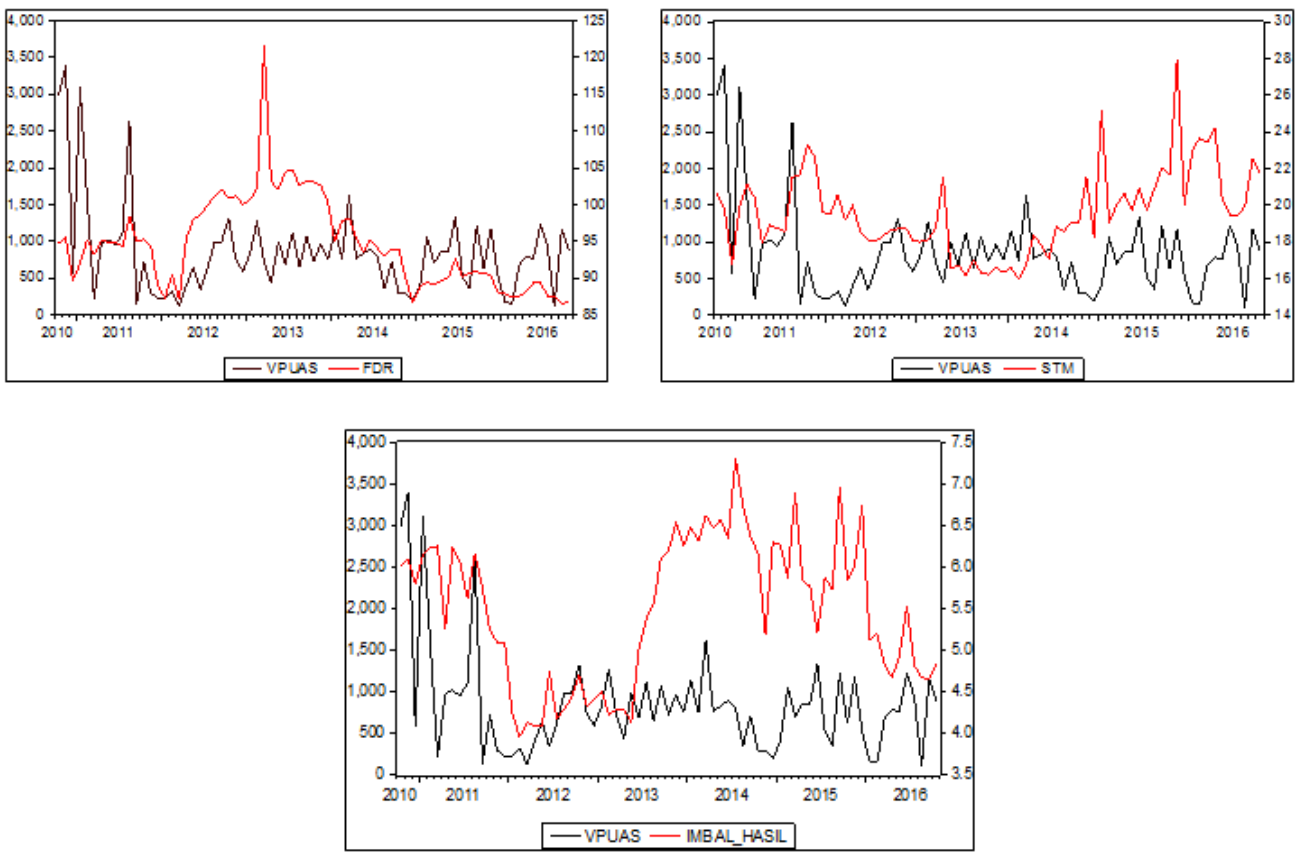

Figure 2. Indonesia Islamic Banking Data Statistics and Financial Service Authority,

(Source: Data Processing Result)

ISSN: 1829-8680 E-ISSN: 2599-0039 
It shows FDR in period October 2010 - October 2016 was in the range of $86.43 \%$ - $121.50 \%$, it indicates the ability of Islamic banks in managing liquidity risk is ranked inadequate and weak. The Islamic banks have great potential in the face of liquidity risk. In January 2014 - October 2016 the average ratio FDR Islamic banking is below 100\%, it shows during the period of Islamic banking have average excess liquidity.

The equations model analysis of liquidity risk and Return to the development of Islamic interbank money market with the dependent variable is VIIMM and the independent variable STM, FDR, and Return are as follows:

VIIMM $=-43.27191$ STM + 13.17553 FDR + 69.31867 Return

Equations $\operatorname{Var}\left(\mathrm{e}_{\mathrm{t}}\right): \sigma_{\mathrm{t}}^{2}=2.002558-0.194907\left|\frac{\mathrm{e} t-1}{\sigma \mathrm{t}-1}\right|+0.141077\left(\frac{\mathrm{e} t-1}{\sigma \mathrm{t}-1}\right)+0.843678 \mathrm{~h} \sigma_{\mathrm{t}-1}^{2}$

Table 1. Selection of the Best Model

\begin{tabular}{|c|c|c|c|c|c|c|}
\hline \multirow{2}{*}{ Model } & \multicolumn{3}{|c|}{ Significant $\alpha=5 \%$} & \multirow[b]{2}{*}{ Log Likelihood } & \multirow[b]{2}{*}{ AIC } & \multirow[b]{2}{*}{ SIC } \\
\hline & STM & FDR & Return & & & \\
\hline ARCH (1) & $\mathrm{X}$ & $\mathrm{X}$ & $\sqrt{ }$ & -561.7680 & 15.52789 & 15.68477 \\
\hline GARCH(1,1) & $\mathrm{X}$ & $\sqrt{ }$ & $\sqrt{ }$ & -534.9584 & 14.82078 & 15.00904 \\
\hline ARCH -M $(1,1)$ & $\mathrm{X}$ & $\mathrm{X}$ & $\sqrt{ }$ & -554.0008 & 15.34249 & $\mathbf{1 5 . 5 3 0 7 5}$ \\
\hline TARCH $(\mathbf{1}, \mathbf{1})$ & $\sqrt{ }$ & $\sqrt{ }$ & $\sqrt{ }$ & -554.6402 & 15.38740 & 15.60704 \\
\hline EGARCH(1,1) & $\sqrt{ }$ & $\sqrt{ }$ & $\sqrt{ }$ & -545.7613 & 15.14414 & 15.36378 \\
\hline
\end{tabular}

Evaluate of the best Model
\begin{tabular}{|l|c|c|c|c|}
\hline \multirow{2}{*}{ Model } & \multicolumn{4}{c|}{ Evaluation test } \\
\cline { 2 - 5 } & ARCH - LM & $\begin{array}{c}\text { Histogram } \\
\text { Normality Test }\end{array}$ & $\begin{array}{c}\text { Correlogram Q } \\
\text { Statistic }\end{array}$ & Unit Root Test \\
\hline ARCH (1) & $\sqrt{ }$ & X & $\sqrt{ }$ & X \\
\hline GARCH(1,1) & $\sqrt{ }$ & $\sqrt{ }$ & $\sqrt{ }$ & $\sqrt{ }$ \\
\hline ARCH -M (1,1) & $\sqrt{ }$ & X & $\sqrt{ }$ & $\sqrt{ }$ \\
\hline TARCH (1,1) & $\sqrt{ }$ & $\sqrt{ }$ & $\sqrt{ }$ \\
\hline EGARCH(1,1) & $\sqrt{ }$ & & $\sqrt{ }$ \\
\hline
\end{tabular}

(Source: Data Processing Result)

From the estimation and simulation and evaluation of the ARCH and GARCH models as well as the variants of the ARCH and GARCH models used, it can be concluded that the research used the EGARCH model (1.1) which is assumed to be the best model, with the following outputs: 
Table 2. Relationship of IIMM, FDR, STM and Return

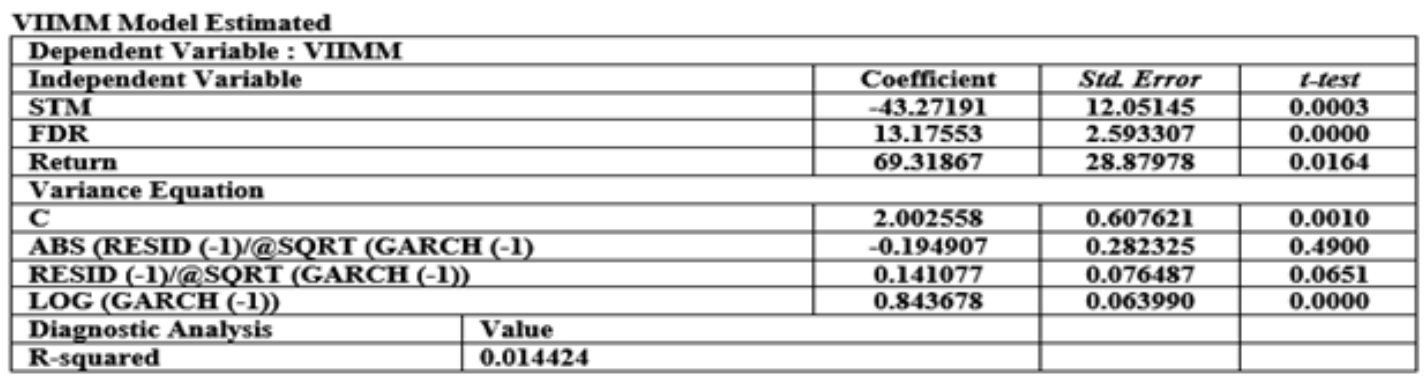

(Source: Data Processing Result)

The output generated from the EGARCH model $(1,1)$ in the table above shows the model with the independent variables STM, FDR and Return are already significant while the residual variance free variable is not significant, but the resulting model is stationary. Based on the estimation of the EGARCH model (1.1) above, the coefficient for each variable is interpreted as follows:

Statistically at the 5\% probability the STM, FDR and Return independent variables significantly influence the VPUAS dependent variable. Every increase in the STM free variable by 1\% will cause a decrease in the VPUAS variable by 43.27191 billion rupiah. Every increase in the FDR-free variable of $1 \%$ will cause an increase in the VPUAS variable of 13,17553 billion rupiah. Every increase in the free return variable by $1 \%$ will cause an increase in the VPUAS variable of 69.31867 billion rupiah.

Statistically at the critical point at $\alpha=5 \%$ it is known that the sign effect shown by the variable (RESID (-1) / @ SQRT (GARCH (-1) is not significant so it can be concluded that there is no difference in effect between positive and negative shocks on period $t$ to the current range, and that the magnitude effect shown by the ABS variable (RESID (-1) / @ SQRT (GARCH (-1) is not significant) so it can be concluded that volatility in the t-1 period does not affect the current range or in other words the above model does not show any asymmetric effect.

ISSN: 1829-8680 E-ISSN: 2599-0039 


\section{RESULTS AND DISCUSSION}

Liquidity risk management in Islamic banking has a significant influence on the development of Islamic interbank money market. Liquidity risk management policy at the Islamic banks have excess liquidity will lead the development of Islamic interbank money market decreased, but when the Islamic banking experience a shortage of liquidity policy of management on these conditions will lead to the development of the Islamic interbank money market increased. Besides that, it is also the development of Islamic interbank money market is significantly affected by short-term liquidity risk policy.

The factors can impact the relationship between liquidity management and Return to the development of IIMM are STM, FDR and Return. The STM ratio has a significant impact, in every increase of $1 \%$ it will cause transaction volume IIMM decreased approximately 43.27 billion rupiah. The FDR ratio has significant impact, in every increase of $1 \%$ will be followed by an increase in volume of IIMM approximately 13.17 billion rupiah. While Returns and IIMM transaction volume has seen a unidirectional relationship with coefficient is positive, in every increase of $1 \%$ in the ratio of Return IIMM will be followed by an increase in the volume of transactions that occur in IIMM approximately 69.32 billion.

The independent variables like STM, FDR and Returns have significant influence on the development of IIMM with the indicated amount by $\mathrm{R}^{2}$ at $1.44 \%$ and the remaining $98.56 \%$ influenced by other variables. It shows the independent variables used get small influence on the development of IIMM.

The prospect of Islamic liquidity risk management issues stems from liquidity risk management policy which IIMM may develop in the conditions of lack of liquidity or liquidity shortage. Besides that, the volatility of IIMM volume was not affected by the volatility of the previous period. It is not shown the differences shocks effect between positive and negative in $t$ period to current, it indicates the actual IIMM in fairly stable conditions. 


\section{CONCLUSION}

Short term liquidity risk policy can impact the development of Islamic interbank money market significantly. Liquidity risk management in Islamic Banking has a significant influence on the development of the IIMM. The liquidity risk management policy when sharia banks experience excess liquidity or what is referred to as excess liqudity will cause the development of sharia interbank money markets to decline and vice versa.

Factors that cause an influence relationship between liquidity management and yields on the development of the Islamic interbank money market are the STM ratio, the FDR ratio and the Return. STM, FDR and Returns influence the development of IIMM as $1,44 \%$. The STM rasio, FDR Rasio has a significant impact, in every increase of $1 \%$ in the ratio of Return IIMM will be followed by an increase in the volume of transactions.

Prospects for sharia liquidity risk management problems stem from liquidity risk management policies in sharia banks where sharia interbank money markets can develop when sharia banks are in a condition of shortage liquidity.

\section{REFERENCES}

Adiwarman. A, Karim. 2004. Bank Islam: Analisis fiqih dan keuangan. Jakarta: PT Raja Grafindo Press

Alamsyah, Halim. 2012. Perkembangan dan Prospek Perbankan Syariah Indonesia: Tantangan dalam Menyongsong MEA 2015. Bank Indonesia.

Bambang, Juanda and Junaidi. 2012. Ekonometrika deret waktu: teori dan aplikasi. Bogor: PT Penerbit IPB Press.

ISSN: 1829-8680 E-ISSN: 2599-0039 
Cetorelli, Nicola and Linda S. Goldberg. 2010. "Global Banks and International Shock Transmission: Evidence from the Crisis”, NBER Working Paper Series, Working Paper 15974.

Greuning, Hennie Van dan Zamir Iqbal. 2011. Analisis risiko perbankan syariah. Jakarta: Salemba Empat.

Hendri, Tanjung dan Abrista Devi. 2013. Metodologi penelitian ekonomi islam. Jakarta: Gramata Publishing.

Imam, Wahyudi et al. 2013. Manajemen risiko bank islam. Jakarta: Salemba Empat.

Irham, Fahmi. 2011. Manajemen risiko: teori, kasus dan solusi. Bandung: Alfabet.

Irsadunas. 2004. Analisis terhadap faktor-faktor yang mempengaruji posisi outstanding SWBI. Tesis. PSKTTI-UI.

Kahf, Monzer. 1995. Ekonomi Islam. Telaah Kritik Terhadap Fungsi Sistem Ekonomi Islam. Yogyakarta: Pustaka Pelajar.

Masyhud, Ali. 2006. Manajemen risiko: Strategi Perbankan dan Dunia Usaha menghadapi Tantangan Globalisasi Bisnis. Jakarta: PT Raja Grafindo Persada.

Muhammad. 2002. Kebijakan fiskal dan moneter dalam ekonomi islam. Jakarta: Salemba Empat.

Nachrowi, D. Nachrowi and Hardius Usman. 2006. Ekomometrika: pendekatan populer dan praktis untuk analisis ekonomi dan keuangan. Jakarta: Lembaga Penerbit Fakultas Ekonomi Universitas Indonesia.

ISSN: 1829-8680 E-ISSN: 2599-0039 
Nazaruddin, Abdul Wahid. 2010. Sukuk: Memahami dan membedah obligasi pada perbankan syariah. Yogyakarta: Ar-Ruzz Media.

Nurul,Huda et al. 2008. Ekonomi makro islam: pendekatan teoretis. Jakarta: Kencana Prenada Media Group.

Sri, Widyastuti and Deki Anwar. 2009. Penggunaan variabel instrumen moneter syariah untuk menganalisa kinerja perbankan syariah. Akuntabilitas Vol.8, No. 2.

Sugestie, Putri Fariska and Nurdin Sobari. 2013. Analisis Pengaruh Risiko Likuiditas dan Imbal Hasil PUAS Terhadap Perkembangan Pasar Uang Antarbank Syariah. Tesis. PSKTTI-UI.

Syukri, Iska. 2012. Sistem perbankan syariah di Indonesia: Dalam Perspektif Fikih Ekonomi. Yogyakarta: Fajar Media Press.

T. Rifqy, Thantawi. 2005. Pengaruh kebijakan moneter terhadap kinerja perbankan syariah. Tesis. PSKTTI-UI.

Umer, Chapra. 2000.Sistem moneter islam. Jakarta: Gema Insani Press.

Zaid, 'Abdul 'Azhim Jalal Abu. 2011. Fiqih Riba: Studi komperhensif tentang riba sejak zaman klasik hingga modern. Jakarta: Senayan Publishing.

Zainul, Arifin. 2003. Dasar-dasar manajemen bank syariah. Jakarta: Alfabet.

Zulverdi, Doddy et al. 2004. "Pengembangan Model Portofolio Bank", Working Paper DKM BI. 